\title{
Development of Service Outsourcing Based on Gray Correlation Factors Theory
}

\author{
Jiahui Liu, a , Guangqiu Lu, ${ }^{1, b}$ and Fuling $\mathrm{Li}^{1, \mathrm{c}}$ \\ ${ }^{1}$ College of mechanical and electrical engineering, Qingdao Binhai University, Qingdao 266555 , \\ Shandong Province, China \\ a1193121893@qq.com, b156360093@qq.com, 602911490@qq.com,
}

Keywords: Service outsourcing; Associated factors; Existing problems; Development measures

\begin{abstract}
Outsourcing has a load of information technology and high added value and low resource consumption, less environmental pollution, creating jobs ability and other characteristics. Therefore accelerating the development of service outsourcing industry, promoting and upgrading the city's industrial structure optimization, promoting economic growth pattern has practical significance to the very best. Qingdao is one of the coastal open cities of the first 14, with a special national policies at the regional level economic and technological development zones, bonded port, high-tech industrial development zones and export processing zones. It has better regional advantages, high social honor and strong economic strength, economic output, and the city's comprehensive strength among the top ten domestic cities. In addition, Qingdao port, highway, railway, aviation and other infrastructure relatively well developed compared with our other outsourcing base has a clear advantage. Currently Qingdao is in transition period of accelerated internationalization, promotion of urbanization, industrialization. Therefore attend and accelerate the development of service outsourcing industry, promote the optimization and upgrade industrial structure in Qingdao is very important to change the way of economic growth, promote better and more economical economic and social development.
\end{abstract}

\section{Introduction}

As the world's emerging industries and high-end service, outsourcing industry can accelerate the upgrading of industrial structure, attract more foreign investment, increase trade in services export revenues, and improve their overall skills. However, Qingdao service outsourcing industry is in its infancy, and there are many problems, therefore propose and analyze the problems, pose the corresponding measures for the development of Qingdao.

\section{Service Outsourcing Review}

Status of Domestic and Foreign Service Outsourcing Research. Current research on outsourcing is done almost all of the international management consultancy such as McKinsey. Mainly from studies of outsourcing Employer perspective. Mainly from the following three aspects: First, the outsourcing of motivation, site selection, risk. Second, the main use of the statistics, analysis and empirical case for the economic effects of outsourcing generated were analyzed. The final step is to study the relationship between employment and outsourcing. [1]

Our service outsourcing started late and has aroused wide concern by governments and enterprises only in recent years. Relevant information and data are also less. At present domestic research on outsourcing only is at the beginning stage. "Introduction to Outsourcing" (Yingluo Wang, 2007) in the book describes what is outsourcing and how Chinese enterprises to undertake outsourcing, which is a more comprehensive description of outsourcing monograph. "Economic analysis of outsourcing: product Division Perspective" (Feng Lu, 2007) in income on service outsourcing-cost analysis and product division from the perspective of interpretation outsourcing. In addition, in 2007 Rongchun Jiang proposed some outsourcing development strategy, Xingfeng Xu 
do the research on each service outsourcing advantage and the status of China's service outsourcing and put forward some development strategies. Lei Gu and Siqi Liu analyzed developing countries arising from economic effects of outsourcing from the Chinese point of view as the Employer.

Based on previous research using quantitative theoretical model of gray correlation analysis of the impact of Qingdao development of service outsourcing related factors put forward countermeasures and suggestions for the development of service outsourcing in Qingdao.

Qingdao Service Outsourcing Development Status. In 2011, the Qingdao offshore outsourcing delivery $\$ 160$ million; in 2012, the city's offshore outsourcing delivery $\$ 350$ million. By the end of 2013, Qingdao service outsourcing enterprises reached 547, delivery \$ 610 million in 2014, outsourcing delivery $\$ 840$ million in 2015, the city's service outsourcing delivery $\$ 1.63$ billion. [2] micro-mechanism and macro mechanism to promote economic development from the perspective of service outsourcing, outsourcing services have developed rapidly in the last decade, mainly due to the advantages of having a more continuous development (1) Information Technology (2) Infrastructure Perfection (3) human resources availability. Although Qingdao obtains rapid development of service outsourcing relatively, but still far behind the pace of development of international service outsourcing industry, is difficult to seize this historic opportunity fully to shift the world's service industry to achieve rapid and stable development. Therefore, we will analyze the reasons that Qingdao outsourcing development is lagging behind.

\section{Analysis with Qingdao Development of Service Outsourcing}

Factors Associated with Qingdao Development of Service Outsourcing. Grey correlation analysis is proposed by Huazhong University of Science Professor Deng Julong in the 1980s [3]. According to the data availability, selected Qingdao service outsourcing relevant data from 2011 to 2015 , service outsourcing income of systemic characteristic sequence $\left(\mathrm{X}_{0}\right)$, influence the underlying determinants of outsourcing have infrastructure, human resources and related expenditure of funds. Human resources professionals are generally considered confined quality is an important aspect of the limiting factors of outsourcing, the number of the main college and above of Qingdao $\left(\mathrm{X}_{1}\right)$, the number of $\mathrm{R} \& \mathrm{D}\left(\mathrm{X}_{2}\right)$ The total expenditure $\left(\mathrm{X}_{3}\right), \mathrm{R} \& \mathrm{D}$ spending $\left(\mathrm{X}_{4}\right)$; from the associated infrastructure, the contemporary IT technology outsourcing services built on the basis of the conditions related to the construction of infrastructure and a greater reliance requires quite intensive service outsourcing business trip, thus infrastructure and facilitation of business travel is a necessary condition. Terms of infrastructure on the main factors affecting outsourcing selected four factors action sequences, sea and air passenger traffic (million) $\left(\mathrm{X}_{5}\right)$, railway and highway passenger miles $\left(\mathrm{X}_{6}\right)$, telephone penetration (per hundred households use telephone households measure) $\left(\mathrm{X}_{7}\right)$, the Internet penetration rate (per hundred households use broadband households measure) ( $\mathrm{X}_{8}$ ). Specific data Table 2-1.

Table 2-1 Main associated factors statistical data

\begin{tabular}{c|c|c|c|c|c|c|c|c|c}
\hline year & $\begin{array}{c}\text { Revenue } \\
\text { \$ bllion } \\
)\end{array}$ & $\begin{array}{c}\text { college } \\
\text { education }\end{array}$ & $\begin{array}{c}\mathrm{R} \& \\
\mathrm{D}\end{array}$ & $\begin{array}{l}\text { Total } \\
\text { expenditur } \\
\mathrm{e}\end{array}$ & $\begin{array}{c}\mathrm{R} \& \mathrm{D} \\
\text { expenditu } \\
\text { re }\end{array}$ & $\begin{array}{c}\text { sail and } \\
\text { air }\end{array}$ & $\begin{array}{c}\text { Road } \\
\text { rail }\end{array}$ & phone & Internet \\
\hline 2011 & 1.6 & 46114 & 3234 & 105000 & 35622 & 1252.9 & 17764 & 2537.46 & 82.38 \\
\hline 2012 & 3.5 & 55931 & 4291 & 123958 & 36073 & 1319.2 & 18562 & 3228.47 & 122.13 \\
\hline 2013 & 6 & 68354 & 5432 & 144909 & 48303 & 1446.9 & 19901 & 3651.55 & 167.09 \\
\hline 2014 & 8.425 & 75198 & 6709 & 183264 & 62920 & 1432.9 & 21187 & 4332.59 & 245.73 \\
\hline 2015 & 16.34 & 89475 & 9727 & 254161 & 128023 & 1585.9 & 21037 & 4638.07 & 277.67 \\
\hline
\end{tabular}


Data Processing and Computing Related Degree. According to the theory of gray correlation, the correlation coefficient is calculated as follows:

$$
y_{i}\left(x_{0}(k), x_{i}(k)\right)=\frac{\min _{i} \min _{k}\left|x_{0}(k)-x_{i}(k)\right|+\xi \max _{i} \max _{i}\left|x_{0}(k)-x_{i}(k)\right|}{\left|x_{0}(k)-x_{i}(k)\right|+\xi \max _{i} \max _{k}\left|x_{0}(k)-x_{i}(k)\right|}
$$

In which the molecules of the two first term represents the minimum difference, the second term represents the two biggest difference. $\xi$ is Resolution factor $(0<\xi<1)$, $\Delta i(k)=|x O(k)-x i(k)| ; i=1,2,3,4,5,6,7,8$ 得

$$
\begin{aligned}
& \Delta 1=(0,0.97,2.27,3.64,8.27) \\
& \Delta 3=(0,1.09,2.54,3.55,7.54) \\
& \Delta 5=(0,1.13,2.60,4.12,8.95) \\
& \Delta 7=(0,0.92,2.31,3.56,8.38)
\end{aligned}
$$

$$
\begin{gathered}
\Delta 2=(0,0.86,2.07,3.19,6.59) \\
\Delta 4=(0,0.52,1.30,1.24,2.48) \\
\Delta 6=(0,1.14,2.63,4.07,9.03) \\
\Delta 8=(0,0.95,1.96,2.77,5.26)
\end{gathered}
$$

Based on the above data, we can calculate the difference between the two

$$
\begin{gathered}
M=\max _{i} \max _{k} \Delta_{i}(k)=9.03 \\
\mathrm{~m}=\min _{i} \min _{k} \Delta_{i}(k)=0.00
\end{gathered}
$$

$\xi=0.5$, so $\gamma_{0 i}\left(x_{0}(k), x_{i}(k)\right)=\frac{4.51}{\Delta i(k)+4.51} i=1,2,3,4,5,6,7,8$

$0<\xi<1,0$ is completely unrelated, 1 indicates perfect correlation, Therefore, the service outsourcing revenue associated with each gray correlation coefficient Table.

Table 2-3 Each relevant factors g correlation coefficient

\begin{tabular}{c|c|c|c|c|c}
\hline Each factor & 2011 & 2012 & 2013 & 2014 & 2015 \\
\hline $\mathrm{x} 1$ & 1.00 & 0.82 & 0.67 & 0.55 & 0.35 \\
\hline $\mathrm{x} 2$ & 1.00 & 0.84 & 0.69 & 0.59 & 0.41 \\
\hline $\mathrm{x} 3$ & 1.00 & 0.80 & 0.64 & 0.56 & 0.37 \\
\hline $\mathrm{x} 4$ & 1.00 & 0.90 & 0.78 & 0.78 & 0.65 \\
\hline $\mathrm{x} 5$ & 1.00 & 0.80 & 0.63 & 0.52 & 0.34 \\
\hline $\mathrm{x} 6$ & 1.00 & 0.80 & 0.63 & 0.53 & 0.33 \\
\hline $\mathrm{x} 7$ & 1.00 & 0.83 & 0.66 & 0.56 & 0.35 \\
\hline $\mathrm{x} 8$ & 1.00 & 0.83 & 0.70 & 0.62 & 0.46 \\
\hline
\end{tabular}

According to the theory of gray correlation, correlation degree is calculated as follows:

$$
\gamma_{0 i}=\frac{1}{\mathrm{n}} \sum_{k=1}^{n} \gamma_{0 i}(k) \quad \mathrm{i}=1,2,3,4,5,6,7,8 ; \mathrm{n}=5
$$

So Qingdao outsourcing revenue factors associated with each degree of association in the following Table 2-4. 
Table 2-4 Service outsourcing income and the associated factors correlation

\begin{tabular}{l|c|c}
\hline \multicolumn{1}{c|}{ Factor } & Correlation & Sequence \\
\hline College education & 0.678 & 5 \\
\hline R \& D personnel & 0.706 & 3 \\
\hline Total expenditure & 0.674 & 6 \\
\hline R \& D expenditure & 0.822 & 1 \\
\hline sail and air & 0.658 & 7 \\
\hline Road rail & 0.658 & 8 \\
\hline phone & 0.680 & 4 \\
\hline Internet & 0.722 & 2 \\
\hline
\end{tabular}

According to the gray correlation degree of gray system theory to calculate the expenses derived outsourcing $\mathrm{R} \& \mathrm{D}$ funding, infrastructure, in particular to improve communication facilities and professional and technical personnel, especially $\mathrm{R} \& \mathrm{D}$ staff is the most important factor in the development of service outsourcing in Qingdao.

\section{Conclusion}

Theoretical analysis based on gray correlation factors obtained Qingdao process outsourcing industry in the future development should be particular emphasis on the following aspects:

Business and government should increase investment in technology research and development outsourcing and innovation intensity of attention, lack of $\mathrm{R} \& \mathrm{D}$ spending will lead to inadequate capacity to undertake international service outsourcing, and not to the rapid development of service outsourcing in Qingdao.

The Government should pay attention to training and efforts to introduce high talents, increase the number and proportion of scientific research personnel, as far as possible to promote the development of service outsourcing industry at labor cost advantage

Continue to improve the infrastructure, in particular to improve communication facilities, build first-class service outsourcing software park, efforts to attract big business leader type. Measures should be taken to change the present status of Qingdao outsourcing development both from the micro-level and macro- level.

\section{References}

[1] Guanyu Xu, Song Xu. Summary of Outsourcing Theory [J]. Chinese collective economic. 2009.12.65-66.

[2] Qingdao Service Outsourcing http://www.qingdaosourcing.com/.

[3] Sun Yi. Qingdao Service Outsourcing Development and Countermeasures [J]. Modern Business Trade Industry .2010.

[4] Karen Lapid. Outsourcing and Offshoring under the General Agreement on Trade in Services. Journal of World Trade.2006.2.341-364.

[5] Yi Sun. Situation and countermeasures of service outsourcing in Qingdao [J]. Modern Business Trade Industry .2010.

[6] http://chinasourcing.mofcom.gov.cn/.

[7] Albert Sargent. Outsourcing Relationship Literature [J].Information Systems and Technology. 282-285. 
[8] UinnJB, HilmerF. Strategic outsourcing [J].Sloan management review.1994.40.43-55.

[9] Karen Lapid. Outsourcing and Offshoring under the General Agreement on Trade in Services. Journal of World Trade.2006.2.341-364.

[10]Amiti, Mary, Shang Jin Wei. Service Outsourcing [J].Productivity and Employment Working Paper.2004.7.34-35. 